\title{
PENGARUH PENGGORENGAN BERULANG TERHADAP KUALITAS MINYAK GORENG
}

\author{
Effect of Repeated Frying on The Quality of Cooking Oil \\ 1*Tri Dyah Astuti \\ ${ }^{1}$ Program Studi D IV Analis Kesehatan, Universitas 'Aisyiyah Yogyakarta, Jl. Ringroad Barat No.63, Yogyakarta, Indonesia
}

*e-mail : Tdyah.27@gmail.com

\begin{abstract}
ABSTRAK
Minyak goreng merupakan salah satu bahan pokok dalam kehidupan sehari-hari. Minyak goreng terbuat dari ester asam emak dengan gliserol. Minyak goreng yang digunakan berulang kali dapat berefek buruk pada kesehatan. Pemakaian minyak berulang mengakibatkan kerusakan minyak dan mempengaruhi kualitas dimana idikator kerusakan minyak goreng dapat dilihat dari kadar asam lemak bebas dan peroksida. Untuk mengetahui pengaruh penggorengan berulang terhadap kualitas minyak goreng ditinjau dari parameter kadar asam lemak bebas dan peroksida. Desain penelitian yang digunakan pada penelitian ini adalah kuantitatif dengan eksperimen. Minyak goreng yang digunakan adalah minyak goreng curah dan minyak goreng kemasan dipakai untuk menggoreng materi bahan pangan protein nabati, yaitu tahu. Angka peroksida dan asam lemak bebas dapat diketahui memalui metode titrasi. Hasil pengujian bilangan peroksida mengalami kenaikan mulai dari pengulangan penggorengan ke 3 pada minyak bermerk dan pengulangan ke 2 pada minyak curah. Bilangan peroksida yang didapat lebih tinggi dari yang disyaratkan SNI $(1.00 \mathrm{mg} \mathrm{O} / 100 \mathrm{~g})$. Pemeriksaan kadar asam lemak bebas pada sampel minyak bermerk dan minyak curah menunjukkan bahwa semua sampel sesuai dengan syarat mutu minyak yang ditetapkan oleh SNI (Maks 0.30\%b/b).
\end{abstract}

Kata kunci : Minyak Goreng, Protein Nabati, Asam Lemak Bebas, Angka Peroksida

\section{ABSTRACT}

Cooking oil is one of the basic ingredients in everyday life. Cooking oil is made from the mother's acid ester with glycerol. Cooking oil that is used repeatedly can have a bad effect on health. The use of recurrent oil results in oil damage and affects the quality where the indicator of damage to cooking oil can be seen from the levels of free fatty acids and peroxides. To determine the effect of repeated frying on the quality of cooking oil in terms of the parameters of the levels of free fatty acids and peroxides. The research design used in this study is quantitative with experiments. The cooking oil used is bulk cooking oil and packaged cooking oil used to fry vegetable food ingredients, namely tofu. Numbers of peroxide and free fatty acids can be known through the titration method. The peroxide number test results have increased from repetition of the third frying to branded oil and second repetition of bulk oil. Peroxide numbers obtained are higher than required by SNI (1.00 mg O2 / 100g). Examination of the levels of free fatty acids in samples of branded oil and bulk oil shows that all samples are in accordance with the oil quality requirements set by SNI (Max. $0.30 \% \mathrm{~b} / \mathrm{b})$.

Keyword: Cooking Oil, Vegetable Protein, Free Fatty Acids, Peroxide Numbers

\section{PENDAHULUAN}

Minyak merupakan campuran dari ester asam lemak dengan gliserol. Jenis minyak umumnya dipakai untuk menggoreng adalah minyak nabati seperti minyak sawit, minyak kacang tanah, minyak wijen dan sebagainya. Minyak goreng jenis ini mengandung sekitar $80 \%$ asam lemak tak jenuh jenis asam oleat dan linoleat, kecuali minyak kelapa (Sartika, 2009). Minyak juga berfungsi sebagai sumber dan pelarut bagi vitamin. vitamin A, D, E dan K (Ketaren, 2008).

Lemak dan minyak sebagian besar dalam alam terdiri dari atas 98-99\% trigliserida. Trigliserida adalah ester gliserol, suatu alkohol trihidrat dan asam lemak yang tepatnya disebut triasilgliserol. Bila ketiga asam lemak di dalam asam trigliserida adalah asam lemak yang sama dinamakan trigliserida sederhana bila berbeda dinamakan trigliserida campuran (Almatseir, 2009).

Penggorengan merupakan fenomena transpor yang terjadi secara simultan, yaitu transfer panas, transfer massa air, dan transfer (serapan) massa minyak. Saat proses peng gorengan dilakukan, terjadi transfer panas dari minyak ke bahan pangan, penguapan massa air, dan penyerapan minyak oleh 
BJMLT

bahan pangan. Suhu penggorengan yang dianjurkan adalah $177-201^{\circ} \mathrm{C}$, atau tergantung jenis bahan yang digoreng (Winarno, 2004).

Pemakaian minyak dengan suhu tinggi dan digunakan secara berulang akan mengakibatkan minyak mengalami kerusakan karena adanya oksidasi yang mampu menghasilkan senyawa aldehida, keton, serta senyawa aromatis yang mempunyai bau tengik (Mariod et al, 2006).

Proses pemanasan minyak pada suhu tinggi dengan adanya oksigen akan mengakibatkan rusaknya asam-asam lemak tak jenuh yang terdapat didalam minyak, seperti asam oleat dan asam linoleat. Kerusakan minyak akibat pemanasan dapat diamati dari perubahan warna, kekentalan, peningkatan kandungan asam lemak bebas, kenaikan bilangan peroksida dan kenaikan kandungan urea adduct forming ester. Selain iti, dapat dilihat dari penurunan bilangan iod dan penurunan kandungan asam lemak tak jenuh (Febriansyah, 2007).

Menurut Wijana dkk.,2005, kerusakan utama minyak adalah timbulnya bau dan rasa tengik, sedangkan kerusakan lain meliputi peningkatan kadar asam lemak bebas (FFA), bilangan iodium, angka peroksida, TBA, angka karbonil, timbulnya kekentalan minyak, terbentuknya busa dan adanya kotoran dari bumbu yang digunakan dan dari bahan yang digoreng. Semakin sering digunakan tingkat kerusakan minyak akan semakin tinggi. Penggunaan minyak berkali-kali akan mengakibatkan minyak menjadi cepat berasap atau berbusa dan meningkatkan warna coklat atau flavor yang tidak disukai pada bahan makanan yang digoreng.

Berdasarkan uraian diatas, maka perlu dilakukan penelitian tentang Pengaruh pengorengan berulang materi protein nabati terhadap kadar asam lemak bebas dan angka peroksida pada minyak curah dan minyak kemasan. Penelitian ini bertujuan untuk : 1) Mengetahui pengaruh jenis minyak goreng hasil penggorengan berulang terhadap kadar asam lemak bebas dan angka peroksida. 2)Mengetahui pengaruh pemakaian minyak goreng secara berulang terhadap kadar asam lemak bebas dan angka peroksida. 3)Mengetahui batas pengulangan pemakaian minyak goreng yang direkomendasikan SNI.

\section{METODE PENELITIAN}

Desain penelitian yang digunakan pada penelitian ini adalah kuantitatif dengan eksperimen. Sampel yang digunakan oleh peneliti adalah minyak goreng curah dan minyak goreng kemasan dipakai untuk menggoreng materi bahan pangan protein nabati, yaitu tahu serta dilakukan pengulangan dalam penggorengan sebanyak 7 kali. Penentuan angka peroksida dan kadar asam lemak bebas dilakukan di Laboratorium Analisis Makanan dan Minuman Universitas 'Aisyiyah Yogyakarta.

\section{Alat dan Bahan}

Alat yang digunakan dalam penelitian ini adalah timbangan analitik, alat-alat gelas laboratorium, saringan, dan kompor. Bahan-bahan yang digunakan dalam penelitian ini adalah minyak goreng curah dan minyak goreng kemasan,tahu, etanol pa (E-Merck), $\mathrm{NaOH}$ pa (E-Merck), indikator fenolftalein (pp), indikator amilum, KI kristal, $\mathrm{Na} 2 \mathrm{~S} 2 \mathrm{O} 3.5 \mathrm{H} 2 \mathrm{O}$, kloroform, asam asetat glasial, dan akuades.

\section{Persiapan Sampel}

Disiapkan bahan pangan yang akan digoreng berupa tahu. Bahan dicampur dengan bumbu. Dimasukkan minyak goreng dalam alat penggorengan sebanyak 1 liter dan nyalakan. Bahan pangan digoreng hingga matang kemudian diangkat dan ditiriskan. Minyak hasil penggorengan diambil sebagian dan disebut sebagai sampel minyak hasil penggorengan ke-1. Kemudian sisanya digunakan untuk menggoreng bahan pangan kembali dan diulangi sebanyak 6 kali dengan menggunakan minyak goreng hasil penggorengan yang sama dan bahan pangan yang sama pula. Sampel minyak goreng hasil penggorengan ke1, 2, 3, 4, 5, 6 dan 7 yang diperoleh ditentukan kadar asam lemak bebas dan bilangan peroksidanya, begitu pula minyak goreng curah dan minyak kemasan yang belum dipakai untuk menggoreng sebagai kontrol.

\section{Penentuan Angka Peroksida}

Sampel ditimbang sebanyak 5 gram dan dimasukkan ke dalam Erlenmeyer $250 \mathrm{~mL}$. Ditambahkan $50 \mathrm{~mL}$ asam asetat glasial-kloroform (3:2), tutup erlenmeyer dan aduk hingga larutan homogen. Ditambahkan larutan kalium iodida jenuh dengan menggunakan pipet ukur, kemudian kocok selama 1 menit. Ditambahkan $30 \mathrm{~mL}$ akuades kemudian tutup Erlenmeyer dengan segera. Kocok 
dan dititrasi dengan larutan natrium tiosulfat $0,1 \mathrm{~N}$ hingga warna kuning hilang, kemudian ditambahkan indikator amilum $0,5 \mathrm{~mL}$ dan dilanjutan titrasi. Kocok kuat untuk melepaskan semua iod dari lapisan pelarut hingga warna biru hilang. Dilakukan penetapan duplo dan blanko.

Bilangan peroksida dinyatakan dalam sampel dihitung dan dinyatakan sebagai miliekivalen $\mathrm{O} 2$ per gram lemak, dengan menggunakan rumus :

Bilangan peroksida (Mek O2/g)

$=\frac{1000 \times \mathrm{N} \times(\mathrm{V} 0-\mathrm{V} 1)}{\mathrm{W}}$

Keterangan :

$\mathrm{N}$ : Normalitas larutan standar natrium thiosulfat $0,01 \mathrm{~N}$ dinyatakan dalam $(\mathrm{N})$

Vo : Volume larutan natrium thiosulfat $0,1 \mathrm{~N}$ yang diperlukan dalam titrasi. Contoh, dinyatakan dalam mililiter (ml)

V1 : Volume larutan natrium thiosulfat $0,1 \mathrm{~N}$ yang diperlukan pada titrasi blangko, dinyatakan dalam milimeter $(\mathrm{ml})$

W : Bobot, contoh dinyatakan dalam gram (g)

\section{Analisis Asam Lemak Bebas}

Sampel ditimbang sebanyak 5 gram dan dimasukkan ke dalam Erlenmeyer $250 \mathrm{~mL}$. Dilarutkan dengan 50 $\mathrm{ml}$ etanol $95 \%$ hangat dan ditambahkan 5 tetes indikator phenopthalin. Dititrasi dengan $\mathrm{KOH} 0,1 \mathrm{~N}$ sampai terbentuk larutan berwarna merah muda. Dicatat volume $\mathrm{KOH}$ yang digunakan. Asam lemak bebas dalam sampel dihitung menggunakan rumus :

Kadar Asam Lemak Bebas

$=\frac{\mathrm{a} \times \mathrm{N} \times \mathrm{BM} \text { Asam Lemak }}{\mathrm{g} \times 1000} \times 100$

Keterangan :

a : Volume $\mathrm{KOH} 0.1 \mathrm{~N}$

$\mathrm{N}$ : Normalitas $\mathrm{KOH}$

g : Berat Sampel

200 : Berat Molekul Asam Laurat

256 : Berat Molekul Asam Palmita

\section{HASIL DAN PEMBAHASAN Bilangan Peroksida}

Penentu kerusakan minyak salah satunya yaitu bilangan peroksida. Penentuan angka peroksida digunakan sebagai ukuran sejauh mana reaksi ketengikan telah terjadi selama penyimpanan.
Bilangan ini dapat digunakan sebagai petunjuk kualitas dan stabilitas lemak dan minyak (Ekwu, 2004). Jumlah peroksida yang terdapat dalam minyak ditetapkan dengan metode iodometri. Pada metode iodometri, iod mereduksi peroksida - peroksida yang terbentuk dalam minyak.

Hasil pengujian bilangan peroksida pada sampel minyak bermerk dan minyak curah dengan penggunaan penggorengan berulang disajikan pada Tabel 1.

TABEL 1. Bilangan peroksida pada sampel minyak bermerk dan minyak curah

\begin{tabular}{cccc}
\hline \multicolumn{4}{c}{ Bilangan Peroksida (mg O2/100g) } \\
\hline Ulangan & $\begin{array}{c}\text { Minyak } \\
\text { Bermerk }\end{array}$ & $\begin{array}{c}\text { Minyak } \\
\text { Curah }\end{array}$ & SNI 01-3741-2002 \\
0 & 0.3 & 0.3 & \\
1 & 0.5 & 0.6 & \\
2 & 0.9 & 3.3. & Maks \\
3 & 1.3 & 6.9 & 1.00 \\
4 & 2.2 & 7.1 & \\
5 & 2.7 & 8.4 & \\
6 & 3.3 & 9.0 & \\
7 & 4.1 & 9.5 &
\end{tabular}

Dari tabel 1 diatas menunjukkan hasil pengujian bilangan peroksida mengalami kenaikan mulai dari pengulangan penggorengan ke 3 pada minyak bermerk dan pengulangan ke 2 pada minyak curah. Bilangan peroksida yang didapat lebih tinggi dari yang disyaratkan SNI (1.00 mg O2/100). Minyak atau lemak yang mengandung asam-asam lemak tidak jenuh, dapat teroksidasi oleh oksigen yang menghasilkan suatu senyawa peroksida. Apabila minyak mengalami oksidasi maka senyawa peroksida yang dihasilkan akan meningkat. Selain dari oksidasi oleh oksigen di udara, peningkatan angka peroksida juga dapat disebabkan oleh pemanasan.

Bilangan peroksida yang tinggi menandakan minyak telah teroksidasi, yang ditandai dengan rasa dan bau tengik. Bilangan peroksida menunjukkan tingkat kerusakan minyak karena oksidasi (Lempang, 2016). Pengulangan penggorengan dapat menyebabkan bilangan peroksida melewati batas yang disyaratkan SNI. Semakin banyak jumlah pengulangan penggorengan, maka semakin bertambah waktu kontak minyak dengan suhu tinggi. Suhu merupakan faktor yang berpengaruh terhadap oksidasi minyak, sehingga minyak yang telah digunakan menunjukkan tingkat degradasi oksidatif yang tinggi (Suratno, 2018).

Kadar Asam Lemak Bebas 
Hasil penetapan kadar asam lemak bebas minyak bermerk dan minyak curah dengan penggunaan penggorengan berulang disajikan pada Tabel 2.

TABEL 2. Penetapan Kadar Asam Lemak Bebas Pada Sampel Minyak Bermerk dan Minyak Curah

\begin{tabular}{cccc}
\multicolumn{5}{c}{ Sampel Minyak Bermerk dan Minyak Curah } \\
\hline \multicolumn{4}{c}{ Kadar Asam Lemak Bebas (\%) } \\
\hline \multirow{2}{*}{ Ulangan } & $\begin{array}{c}\text { Minyak } \\
\text { Bermerk }\end{array}$ & $\begin{array}{c}\text { Minyak } \\
\text { Curah }\end{array}$ & $\begin{array}{c}\text { SNI 01-3741- } \\
\mathbf{2 0 0 2}\end{array}$ \\
\hline 0 & 0.0064 & 0.0419 & \\
\hline 1 & 0.0251 & 0.0769 & \\
\hline 2 & 0.0255 & 0.0985 & \\
\hline 3 & 0.0391 & 0.1155 & Maks \\
\hline 4 & 0.0420 & 1.3287 & 0.30 \\
\hline 5 & 0.0477 & 1.4820 & \\
\hline 6 & 0.0592 & 1.7215 & \\
\hline 7 & 0.0684 & 1.7567 & \\
\hline
\end{tabular}

Dari tabel 2 diatas menunjukkan bahwa penetapan kadar asam lemak bebas pada sampel minyak bermerk sesuai dengan syarat mutu minyak yang ditetapkan oleh SNI pada semua sampel. Sedangkan pada minyak curah didapatkan bahwa kadar asam lemak bebas lebih tinggi dari yang ditetapkan SNI yaitu pada pengulangan penggorengan ke 4.

Berdasarkan penelitian yang telah dilakukan untuk menentukan kadar asam lemak bebas, hasil menunjukkan adanya peningkatan kadar asam lemak bebas dari pengulangan penggorengan kesatu hingga ke tujuh. Kadar asam lemak bebas mengalami kenaikan seiring bertambahnya frekuensi penggorengan. Peningkatan persentase disebabkan adanya pertukaran komponen air dalam bahan makanan dengan minyak sebagai media penggorengan. Meskipun kadar asam lemak bebas mengalami peningkatan seiring bertambahnya frekuensi, kadar asam lemak bebasnya masih berada di bawah SNI pada minyak yang bermerk. Sedangkan pada minyak curah mengalami kenaikan kadar asam lemak bebas pada pengulangan penggorengan ke 4 . Nilai kadar asam lemak bebas berkisar $0,30 \% \mathrm{~b} / \mathrm{b}$. Nilai asam lemak bebas di atas batas ambang mengindikasikan kerusakan dalam minyak tersebut. Semakin sering digunakan tingkat kerusakan minyak akan semakin tinggi.

Asam lemak bebas dalam minyak merupakan asam lemak jenuh yang mengandung kolestrol. Semakin besar asam lemak bebas yang terdapat dalam minyak maka semakin besar pula kadar kolestrolnya. Bila minyak tersebut dikonsumsi maka kadar kolestrol dalam darah naik, sehingga terjadi penumpukan lapisan lemak di dalam pembuluh darah yang menyebabkan penyumbatan pembuluh darah. Dengan demikian mudah terserang penyakit jantung (Densi, 2017).

Kenaikan bilangan asam lemak bebas juga dapat disebabkan karena kadar air yang tinggi sehingga mempercepat hidrolisis dari minyak goreng. Keberadaan air pada minyak akan mempercepat proses hidrolisis dari minyak goreng (Lempang, 2016).

\section{KESIMPULAN}

Berdasarkan hasil penelitian, dapat disimpulkan bahwa angka peroksida dalam minyak bermerk dan minyak curah pada penggorengan berulang menyebabkan angka peroksida yang meningkat. Bilangan peroksida yang tinggi disebabkan oleh minyak yang teroksidasi dan adanya pemanasan yang tinggi.

Pada penetapan kadar asam lemak bebas sampel minyak bermerk mengalami peningkanatan tetapi masih memenuhi syarat SNI. Sedangkan pada minyak curah mengalami kenaikan kadar asam lemak bebas pada penggorengan berulang yang ke 4 yang sudah melebihi batas SNI.

\section{DAFTAR PUSTAKA}

Almatsier, S. 2009. Prinsip Dasar Ilmu Gizi. Jakarta, Gramedia Pustaka Utama.

Densi, Selpia Sopianti., Herlina., \& Handi Tri Saputra. 2017. Penetapan Kadar Asam Lemak Bebas pada Minyak Goreng. Jurnal Katalisator. 2(2).

Ekwu, F. C., \& Nwagu, A. 2004. Effect of Processing on The Quality of Cashew Nut Oils. J. Sci. Agric. Food Tech. Environ. 4:105-110.

Febriansyah, R. 2007. Mempelajari Pengaruh Penggunaan Berulang dan Aplikasi Adsorben Terhadap Kualitas Minyak dan Tingkat Penyerapan Minyak Pada Kacang Sulut. Fakultas Teknologi Pertanian Institut Pertanian Bogor, Bogor.

Ketaren, S. 2008. Pengantar Teknologi Minyak dan Lemak Pangan. Jakarta, UI-Press.

Lempang, I. R., Fatimawali, \& Pelealu, N.C. 2016. Uji Kualitas Minyak Goreng Curah dan 


\section{BJMLT}

Minyak Goreng Kemasan di Manado. Pharmacon, 5(4):155-161.

Mariod, A, Matthaus B, Eichner K, Hussein IH. 2006. Frying Quality And Oxidative Stability of Two Unconventional Oils. Journal of the American Oils Chemistry Society. 83(6):529538.

Sartika, R. A. D. 2009. Pengaruh Suhu Dan Lama Proses Menggoreng (Deep Frying) terhadap Pembentukan Asam Lemak Trans. MAKARA SAINS 13(1):23-28.

Suratno \& Utomo, R. V. 2018. Bilangan Peroksida Pada Minyak Goreng Penjual Gorengan Di Jalan Rajawali Kota Palangka Raya. Borneo Journal of Medical Laboratory Technology, 1(1):25-29.

Wijana, Susinggih, et al. 2005. Mengolah Minyak Goreng Bekas. Surabaya, Trubus Agrisarana.

Winarno F.G. 2004. Kimia Pangan dan Gizi. Jakarta, Gramedia Pustaka Utama. 